\title{
Cause of death in cerebral palsy: a descriptive study
}

\author{
Gillian Maudsley, Jane L Hutton, Peter O D Pharoah
}

\begin{abstract}
Background-Cause specific research on death certification in chronic disease has rarely involved cerebral palsy.

Aims-To evaluate cause of death information in people known to have cerebral palsy by: describing the cause of death distribution; determining case ascertainment using death certification as the data source; and analysing the choice of wording and its arrangement in the "cause of death statement".

Study cases and setting-People with early or late impairment cerebral palsy who died by 30 June 1998, on the population based Mersey Cerebral Palsy Register born 1966-91 to mothers resident locally. Study design-Descriptive study of the multiply coded cause of death statements from National Health Service Central Register flagging.

Results-Death certificate copies were acquired for all $282(13.4 \%)$ of the 2102 registered cases who died. Cerebral palsy was the most common "underlying cause of death" (95 of 282; 33.7\%) and was mentioned in a further 61 cases. The underlying cause of death was more likely to be cerebral palsy with increasingly severe disability and was derived from Part II in 16 of 95 cases.

Conclusions-The potential of death certification for case ascertainment of cerebral palsy is important, but limited, even with multiple cause coding. Mortality data need careful interpretation as a proxy source for examining trends and patterns in cerebral palsy.

(Arch Dis Child 1999;81:390-394)
\end{abstract}

Department of Public Health, Whelan Building, Quadrangle, University of Liverpool, Liverpool L69 3GB, UK

G Maudsley

Department of Statistics, University of Newcastle, Newcastle upon Tyne NE1 7RU, UK

J L Hutton

Department of Public Health, Muspratt

Building, Quadrangle, University of Liverpool P O D Pharoah

Correspondence to: Dr Maudsley

Accepted 17 June 1999 used to explain the large reduction in mortality rates and consequent large reduction in birth rates with industrialisation. ${ }^{1}$ The cause of death pattern changes from being dominated by communicable disease ("age of pestilence and famine"), particularly in young people, to chronic disease and injury, particularly in older people. ${ }^{1}$ In Western industrialised countriesfor example, this transition has taken over a century. Nevertheless, even though most morbidity is now attributable to chronic diseases, its cause specific distribution will not be mirrored closely by mortality data because of the effect of co-morbidities.

Second, the "underlying cause of death" is difficult to certify with "accuracy". ${ }^{2}$ This accuracy has both diagnostic and semantic (the choice of terms and their arrangement) components. ${ }^{2}$ Research has focused on expert review of the diagnostic accuracy of the underlying cause of death from clinical information, with or without necropsy information,,$^{3-11}$ in adults; usually describing patterns across broad disease categories. Certifiers often write the "cause of death statement" without understanding the pragmatic convention of single cause coding of mortality data (in which, despite death being multifactorial, only one cause, the underlying cause of death, is derived and coded from the statement). ${ }^{212}$ In the evidence base, however, the way that certifiers write the cause of death statement (the choice of words and their arrangement) has received less attention than has diagnostic accuracy. ${ }^{2}{ }^{12-14}$

The morbidity to mortality data relation and the accuracy of the certified underlying cause of death are both affected by characteristics of the certifier, the certificate, the deceased, and the causes of death. ${ }^{15}$ Chronic diseases might not be, or might not be certified as, the underlying cause of death for reasons that have yet to be investigated systematically. Cause specific research on death certification in chronic disease has tended to focus on-for example, diabetes mellitus ${ }^{16}{ }^{17}$ and rheumatoid disease. ${ }^{18}$ Only Evans and Alberman have studied death certification in people with cerebral palsy $^{19}$; although the pattern of cause of death might be changing as that of birth prevalence changes $^{20}{ }^{21}$ and survival increases. ${ }^{22}$ Consequently, the aim of our study was to evaluate cause of death information in people known to have cerebral palsy by: (1) describing the cause of death distribution; (2) determining the potential case ascertainment, using death certification as the data source, and determining whether this changes over time or with severity; and (3) analysing the choice of terms and their arrangement on the cause of death statement. 
Table 1 Underlying cause of death in people with cerebral palsy (born to Merseyside and Cheshire residents 1966-91) who died by 30 Fune 1998

\begin{tabular}{|c|c|c|c|c|c|}
\hline Code range & Code & Category & $\begin{array}{l}\text { Early and late } \\
\text { impairment } \\
\text { cerebral palsy } \\
(n(\%))\end{array}$ & $\begin{array}{l}\text { Early } \\
\text { impairment } \\
\text { cerebral palsy } \\
(n(\%))\end{array}$ & $\begin{array}{l}\text { Late impairment } \\
\text { cerebral palsy } \\
(n(\%))\end{array}$ \\
\hline I: Infectious and parasitic diseases (001-139) & 049 & $\begin{array}{l}\text { Other non-arthropod borne viral diseases of } \\
\text { central nervous system }\end{array}$ & $3(1.1)$ & $1(0.4)$ & $2(3.6)$ \\
\hline II: Neoplasms (140-239) & 189,204 & $\begin{array}{l}\text { Malignant neoplasm of kidney and other NOS } \\
\text { female genital organs; lymphoid leukaemia }\end{array}$ & $2(0.7)$ & & \\
\hline $\begin{array}{l}\text { III: Endocrine, nutritional and metabolic } \\
\text { diseases and immunity disorders }(240-279)\end{array}$ & 277,279 & $\begin{array}{l}\text { Other and NOS disorders of metabolism; } \\
\text { disorders involving the immune mechanism }\end{array}$ & $2(0.7)$ & $4(1.8)$ & $1(1.8)$ \\
\hline \multirow[t]{2}{*}{ V: Mental disorders (290-319) } & 305 & Non-dependent abuse of drugs & $1(0.4)$ & & \\
\hline & 318,319 & $\begin{array}{l}\text { Other specified mental retardation; NOS } \\
\text { mental retardation }\end{array}$ & $12(4.3)$ & $9(4.0)$ & $3(5.5)$ \\
\hline \multirow{5}{*}{$\begin{array}{l}\text { VI: Diseases of nervous system and sense } \\
\text { organs (320-389) }\end{array}$} & 331 & Other cerebral degenerations & $10(3.5)$ & $8(3.5)$ & $2(3.6)$ \\
\hline & 343 & Infantile cerebral palsy & $79(28.0)$ & $64(28.2)$ & $15(27.3)$ \\
\hline & 344 & Other paralytic syndromes & $16(5.7)$ & $10(4.4)$ & $6(10.9)$ \\
\hline & 345 & Epilepsy & $15(5.3)$ & $11(4.8)$ & $4(7.3)$ \\
\hline & $\begin{array}{l}320,322,323 \\
335,348,349 \\
382,389\end{array}$ & $\begin{array}{l}\text { Bacterial meningitis; meningitis of cause NOS; } \\
\text { encephalitis, myelitis, and encephalomyelitis; } \\
\text { anterior horn disease; other conditions of } \\
\text { brain; other and NOS disorders of central } \\
\text { nervous system; suppurative and NOS otitis } \\
\text { media; deafness }\end{array}$ & $14(5.0)$ & $11(4.8)$ & $3(5.5)$ \\
\hline $\begin{array}{l}\text { VII: Diseases of circulatory system } \\
\quad(390-459)\end{array}$ & $\begin{array}{l}415,427,429 \\
436\end{array}$ & $\begin{array}{l}\text { Acute pulmonary heart disease; cardiac } \\
\text { dysrhythmias; ill defined descriptions and } \\
\text { complications of heart disease; acute but ill } \\
\text { defined cerebrovascular disease }\end{array}$ & $4(1.4)$ & & \\
\hline \multirow[t]{2}{*}{$\begin{array}{l}\text { VIII: Diseases of respiratory system } \\
\qquad(460-519)\end{array}$} & $\begin{array}{l}480,482,485 \\
486\end{array}$ & $\begin{array}{l}\text { Viral pneumonia; other bacterial pneumonia; } \\
\text { bronchopneumonia, organism NOS; } \\
\text { pneumonia, organism unspecified }\end{array}$ & $37(13.1)$ & $29(12.8)$ & $8(14.5)$ \\
\hline & $\begin{array}{l}465,466,478 \\
490,493,496 \\
507,519\end{array}$ & $\begin{array}{l}\text { Acute upper respiratory infections of multiple } \\
\text { or NOS sites; acute bronchitis and } \\
\text { bronchiolitis; other diseases of upper } \\
\text { respiratory tract; bronchitis, NOS as acute or } \\
\text { chronic; asthma; chronic airways obstruction, } \\
\text { NEC; pneumonia as a result of solids and } \\
\text { liquids; other diseases of respiratory system }\end{array}$ & $22(7.8)$ & $20(8.8)$ & $2(3.6)$ \\
\hline IX: Diseases of digestive system (520-579) & $\begin{array}{l}530,531,557 \\
558,560,568 \\
571,577\end{array}$ & $\begin{array}{l}\text { Diseases of oesophagus; gastric ulcer; vascular } \\
\text { insufficiency of intestine; other non-infective } \\
\text { gastroenteritis and colitis; intestinal } \\
\text { obstruction without mention of hernia; other } \\
\text { disorders of peritoneum; chronic liver disease } \\
\text { and cirrhosis; diseases of pancreas }\end{array}$ & $10(3.5)$ & $9(4.0)$ & $1(1.8)$ \\
\hline $\begin{array}{l}\text { X: Diseases of genitourinary system } \\
(580-629)\end{array}$ & 581,599 & $\begin{array}{l}\text { Nephrotic syndrome; other disorders of } \\
\text { urethra }\end{array}$ & $3(1.1)$ & $10(4.4)$ & $1(1.8)$ \\
\hline $\begin{array}{l}\text { XIII: Diseases of musculoskeletal system and } \\
\text { connective tissue }(710-739)\end{array}$ & $733,737,738$ & $\begin{array}{l}\text { Other disorders of bone and cartilage; } \\
\text { curvature of spine; other acquired deformity }\end{array}$ & $4(1.4)$ & & \\
\hline XIV: Congenital anomalies (740-759) & $\begin{array}{l}742 \\
745,746,756 \\
758,759\end{array}$ & $\begin{array}{l}\text { Other congenital anomalies of nervous system } \\
\text { Bulbis cordis anomalies and anomalies of } \\
\text { cardiac septal closure; other congenital } \\
\text { anomalies of heart; other congenital } \\
\text { musculoskeletal anomalies; chromosomal } \\
\text { anomalies; other and NOS congenital } \\
\text { anomalies }\end{array}$ & $\begin{array}{l}13(4.6) \\
5(1.8)\end{array}$ & $16(7.0)$ & $2(3.6)$ \\
\hline $\begin{array}{l}\text { XV: Certain conditions originating in } \\
\text { perinatal period }(760-779)\end{array}$ & $\begin{array}{l}765,767,768 \\
770\end{array}$ & $\begin{array}{l}\text { Disorders relating to short gestation and NOS } \\
\text { low birthweight; birth trauma; intrauterine } \\
\text { hypoxia and birth asphyxia; other respiratory } \\
\text { conditions of fetus and newborn }\end{array}$ & $14(5.0)$ & $12(5.3)$ & $2(3.6)$ \\
\hline $\begin{array}{l}\text { XVI: Symptoms, signs and ill defined } \\
\text { conditions }(780-799)\end{array}$ & 780,798 & $\begin{array}{l}\text { General symptoms; sudden death, cause } \\
\text { unknown }\end{array}$ & $6(2.1)$ & $5(2.2)$ & $1(1.8)$ \\
\hline $\begin{array}{l}\text { XVII: Injury and poisoning (800-999) } \\
\text { external causes E-codes }\end{array}$ & $\begin{array}{l}811,814,878 \\
910,911,928\end{array}$ & $\begin{array}{l}\text { Fracture of scapula; fracture of carpal bones; } \\
\text { open wound of genital organs (external), } \\
\text { including traumatic amputation; superficial } \\
\text { injury of face, neck, and scalp, except eye; } \\
\text { superficial injury of trunk; crushing injury of } \\
\text { lower limb }\end{array}$ & $10(3.5)$ & $8(3.5)$ & $2(3.6)$ \\
\hline Total & & & $282(100)$ & $227(99.9)$ & $55(99.8)$ \\
\hline
\end{tabular}

Data source: Mersey Cerebral Palsy Register.

ICD, international classification of diseases; NEC, not elsewhere classified; NOS, not otherwise specified.

\section{Methods}

The population based Mersey Cerebral Palsy Register (MCPR), covering approximately 2.4 million people, was started in 1980, approved and funded initially by the former Mersey Regional Health Authority research committee. Subsequently, the MCPR has been maintained, using multiple sources of ascertainment (including death certification), through eclectic funding of one researcher. ${ }^{23}$ Registered "cases" are people with cerebral palsy born since 1 January 1966 to mothers resident in the counties of Merseyside and
Cheshire. On the MCPR, cerebral palsy is recorded if a clinical diagnosis has been made (which fulfils the Bax definition $^{24}$ ). It is then categorised according to the probable timing of cerebral impairment, as follows:

- Early impairment cerebral palsy_prenatally or within the first 28 days of life

- Late impairment cerebral palsy-over 28 days of life.

The impairment is assumed to be early unless evidence is found to allocate it to the late category. 
Table 2 Recording of cerebral palsy in the cause of death statements of people with cerebral palsy (born to Merseyside and Cheshire residents 1966-91) who died by 30 fune 1998

\begin{tabular}{|c|c|c|c|}
\hline Underlying cause of death & $n(\%)$ & & \\
\hline Cerebral palsy & $95(33.7)$ & Derived from Part I $I^{\star} 79$ (28.0) & \\
\hline $\begin{array}{l}\text { Not cerebral palsy, but } \\
\text { cerebral palsy mentioned }\end{array}$ & $61(21.6)$ & $\begin{array}{l}\text { Mentioned in Part I } 13(4.6) \\
\text { Mentioned in Part II } 48(17.0)\end{array}$ & $\rightarrow 187(66.3)$ \\
\hline $\begin{array}{l}\text { Not cerebral palsy, } \\
\text { cerebral palsy not } \\
\text { mentioned anywhere }\end{array}$ & $126(44.7)$ & & \\
\hline Total deaths & $282(100)$ & & \\
\hline
\end{tabular}

Data source, Mersey Cerebral Palsy Register.

${ }^{\star}$ Cerebral palsy was also mentioned in Part II for one certificate.

All cases are routinely flagged with the National Health Service Central Register (NHSCR). If a patient on the MCPR dies, this allows the NHSCR to notify the MCPR and provide a copy of the cause of death statement with each entry coded to the four digit level of the international classification of disease (ICD) ninth revision. ${ }^{25}$ All elements of Parts I (immediate, intermediate, and underlying cause of death) and II (contributory cause(s) of death) are coded. The cause of death statement in England and Wales is in the internationally agreed format ${ }^{25}$; the underlying cause of death is therefore the lowermost completed line in Part I: "the disease or injury which initiated the train of morbid events leading directly to death", with more recent conditions above it in the sequence, as appropriate. Contributory causes of death in Part II comprise: "other significant conditions contributing to the death, but not related to the disease or condition causing it".

An MCPR dataset was extracted containing all cases born between 1966 and 1991 (that is, including the most recent year for which ascertainment was unlikely to be substantially improved), and with vital status recorded as at the end of June 1998. The main variables comprised: age, sex, type and severity of cerebral palsy, vital status, date of death, coded entries in Parts I and II of the cause of death statement (including underlying cause of death), birth weight, and gestational age.

Focusing on those cases known to have died, the main analyses comprised:

- The frequency tabulation of the underlying cause of death at the three digit coding level, grouping those accounting for small numbers

- The frequency with which cerebral palsy was mentioned in the cause of death statement, and the ratio of "mentioned anywhere" to underlying cause. (Conditions with a high case fatality rate, such as gastric cancer, will have a ratio close to 1 because they will be mentioned most often as the underlying cause of death. For diabetes mellitus, the ratio was around 4 in both sexes in $1997^{26}$ )

- Cross tabulation of whether cerebral palsy was the underlying cause of death or not with severity of disability and timing of death, respectively

- The frequency with which the underlying cause of death, when it was cerebral palsy, had to be derived from Part II (as an indica- tor of poorer quality completion of the cause of death statement).

For the cause of death statements, cerebral palsy was defined as: ICD 343, "infantile cerebral palsy"; and ICD 344, "other paralytic syndromes", which include quadriplegia, paraplegia, diplegia, and monoplegia.

Disability was characterised using three modalities, ${ }^{22}$ namely: mental-for which an intelligence quotient of $\leqslant 50$ indicated severe disability; manual - for which the inability to feed or dress unaided indicated severe disability; and ambulatory - for which wheelchair dependent mobility indicated severe disability.

Yates corrected $\chi^{2}$ and $\chi^{2}$ for trend were calculated to compare relevant proportions for unordered and ordered categorical data, respectively.

\section{Results}

Of 2102 cases of cerebral palsy flagged with the NHSCR (1203 male, 893 female, six of unknown sex), the MCPR had already received death certificate copies for $282(13.4 \%)$. These came from 227 of 1828 (12.4\%) cases of early impairment cerebral palsy and 55 of 274 $(20.1 \%)$ cases of late impairment cerebral palsy. All certificates were for deaths over 28 days of life. Of the deceased, 178 of 282 $(63.1 \%)$ were male, and $104(36.9 \%)$ were female; 70 of $251(27.9 \%)$ had been low birth weight $(\leqslant 2500 \mathrm{~g})$ and 55 of $238(23.1 \%)$ had been born preterm ( $<37$ weeks).

The most common underlying cause of death (95 of $282 ; 33.7 \%$ ) was cerebral palsy (table 1). The second most common cause was pneumonia $(13.1 \%)$. There was no subsequent pattern in late impairment cerebral palsy. However, in early impairment cerebral palsy, other respiratory conditions (mostly inflammatory; $8.8 \%$ ), and a comparable proportion for combined "other cerebral degenerations"/ "other congenital anomalies of nervous system" (both including hydrocephalus), were jointly the next most common underlying cause of death (table 1). There was no significant difference between the sexes in whether or not cerebral palsy was the underlying cause of death $(\mathrm{p}=0.7)$.

Of the 187 cases $(66.3 \%)$ in which cerebral palsy was not the underlying cause of death, it was still mentioned elsewhere on the cause of death statement in $61(32.6 \%)$ (table 2), giving a ratio of mentioned anywhere/underlying cause of death of 156 to 95 (1.6). Where cerebral palsy was the underlying cause of death, it was derived from Part II in $16.8 \%$.

Most of those who died were severely disabled in all three disability modalities (mental, manual, ambulatory) $(61.3 \%)$, but $38 \%$ of these still had no mention of cerebral palsy in the cause of death statement. Nevertheless, cerebral palsy was statistically very significantly more likely to be certified as the underlying cause of death with increasingly severe disability (table 3). Information was missing on at least one of the disability modalities in a further $22.7 \%$ of cases. This was usually because the child died before the severity of the disability could be assessed. 
Table 3 Recording of cerebral palsy, according to severity of disability, in the cause of death statements of people with cerebral palsy (born to Merseyside and Cheshire residents 1966-91) who died by 30 fune 1998

\begin{tabular}{|c|c|c|c|c|c|c|}
\hline Underlying cause of death & $\begin{array}{l}\text { Not severely } \\
\text { disabled in } \\
\text { any modality }\end{array}$ & $\begin{array}{l}\text { Severely } \\
\text { disabled in any } \\
1 \text { modality }\end{array}$ & $\begin{array}{l}\text { Severely } \\
\text { disabled in any } \\
2 \text { modalities }\end{array}$ & $\begin{array}{l}\text { Severely } \\
\text { disabled in all } \\
3 \text { modalities }\end{array}$ & $\begin{array}{l}\text { Information } \\
\text { missing on } \\
\text { severity of } \\
\text { disability }\end{array}$ & Total \\
\hline Cerebral palsy & $1(9.1)$ & $3(15.8)$ & $6(40.0)$ & 69 (39.9) & $16(25.0)$ & $95(33.7)$ \\
\hline $\begin{array}{l}\text { Not cerebral palsy, but } \\
\text { cerebral palsy mentioned } \\
\text { Not cerebral palsy, }\end{array}$ & $1(9.1)$ & $3(15.8)$ & $3(20.0)$ & $38(22.0)$ & $16(25.0)$ & $61(21.6)$ \\
\hline $\begin{array}{l}\text { cerebral palsy not mentioned anywhere } \\
\text { Total }\end{array}$ & $\begin{array}{l}9(81.8) \\
11\end{array}$ & $\begin{array}{l}13(68.4) \\
19\end{array}$ & $\begin{array}{l}6(40.0) \\
15\end{array}$ & $\begin{array}{l}66(38.2) \\
173\end{array}$ & $\begin{array}{l}32(50.0) \\
64\end{array}$ & $\begin{array}{l}126(44.7) \\
282(100)\end{array}$ \\
\hline
\end{tabular}

Values are $\mathrm{n}(\%)$.

Data source, Mersey Cerebral Palsy Register.

After excluding those with missing information on severity of disability for the underlying cause of death as cerebral palsy or not, the $\chi^{2}$ trend $(1$ degree of freedom $)=7.21 ; \mathrm{p}=0.007$.

Table 4 Recording of cerebral palsy, according to the decade of death, in the cause of death statements of people with cerebral palsy (born to Merseyside and Cheshire residents 1966-91) who died by 30 fune 1998

\begin{tabular}{llllll}
\hline Underlying cause of death & Late 1960s & $1970 s$ & $1980 s$ & 1990s & Total \\
\hline $\begin{array}{l}\text { Cerebral palsy } \\
\text { Not cerebral palsy, but } \\
\quad \text { cerebral palsy mentioned }\end{array}$ & $3(37.5)$ & $20(32.3)$ & $34(30.1)$ & $38(38.4)$ & $95(33.7)$ \\
$\begin{array}{l}\text { Not cerebral palsy, } \\
\quad \text { cerebral palsy not mentioned anywhere }\end{array}$ & $4(50.0)$ & $14(22.6)$ & $15(13.3)$ & $28(28.3)$ & $61(21.6)$ \\
\begin{tabular}{l} 
Total \\
\hline
\end{tabular} & $1(12.5)$ & $28(45.2)$ & $64(56.6)$ & $33(33.3)$ & $126(44.7)$ \\
\end{tabular}

Values are $\mathrm{n}(\%)$.

Data source, Mersey Cerebral Palsy Register.

For the underlying cause of death as cerebral palsy or not, the $\chi^{2}$ trend $(1$ degree of freedom $)=1.74 ; \mathrm{p}=0.63$.

There was a suggestion that a smaller proportion of the cause of death statements omitted cerebral palsy by the 1990s compared with the 1970s and 1980s (table 4). There was, however, no significant trend in the likelihood of cerebral palsy being the certified underlying cause of death over the four decades.

\section{Discussion}

In our study, although cerebral palsy was the most common underlying cause of death, this only accounted for approximately one third of deaths. Consequently, mortality data need careful interpretation when used as a proxy source for examining trends and patterns in cerebral palsy. Admittedly, the diagnostic validity of the certified compared with the "true" underlying cause of death cannot be assessed without systematic expert review of clinical and postmortem information, and this would be an area for further cause specific research. However, according to our study there might be considerable under recording of cerebral palsy in mortality data. For example, many of the deaths attributed to respiratory tract infection possibly merited having cerebral palsy recorded as the antecedent in the causal sequence. Nevertheless, this discussion is also affected by the caveat that, for deaths between 1984 and 1992, the Office for National Statistics applied a wider interpretation of the ICD coding rule 3 than prevailed internationally. ${ }^{27}$ Rule 3 states that: "If the condition selected . . . can be considered a direct sequel of another reported condition, whether in Part I or Part II, select this primary condition". ${ }^{25}$ For 1984-92 deaths, however, even without noting a "direct causal" relation, the Office for National Statistics interpreted the rule to allow the selection of immobilising, disabling, and debilitating conditions from Part II when terminal conditions, such as bronchopneumonia, were alone in Part I. The Office for
National Statistics reverted to the narrower, international interpretation of rule 3 when its cause coding was automated, for deaths from 1993 onwards, because the coding software from the USA included this interpretation.

The potential case ascertainment achievable through death certification is important, but limited, even with multiple cause coding of causes of death. Cerebral palsy was not mentioned at all in the cause of death statement of $45 \%$ of those who died, but was more likely to be the underlying cause of death with increasingly severe disability. There was no clear time trend in the pattern of certifying cerebral palsy, but more time needs to elapse to confirm if there really was a more recent, increasing tendency to include cerebral palsy in the cause of death statement. (Because the register only started with births in 1966, relatively few deaths could be expected in the remainder of that decade.)

Assessing the quality of the cause of death statement by the choice of terms and their arrangement, the underlying cause of death should be the condition triggering the causal sequence leading to death-the lowermost entry in Part I. In well constructed sequences for single cause coding of mortality data, the "general rule" of the international coding rules selects the entry from this position. To derive the underlying cause of death, supplementary coding rules are only applied if the causal sequence is incorrectly constructed. The frequency with which the underlying cause of death is obtained from Part II is, therefore, one indicator of the quality of death certification. In our study, of the 95 cases with cerebral palsy as the underlying cause of death, one sixth were obtained from Part II, indicating a lapse in the quality of death certification. The ratio of 1.6 for mentioned anywhere/underlying cause in cerebral palsy compares with 1.6 and 2.1 for male, and 1.8 and 1.9 for female patients, for 
code 343, in England and Wales, in 1985 and 1997, respectively (C Rooney, Office for National Statistics, personal communication, 1999).

The findings reported here are similar to those reported from the South East Thames Register of Cerebral Palsy, covering 73 deaths in 732 children with cerebral palsy (born 1970-79, followed up to 1989). ${ }^{19}$ Cerebral palsy was reported to be the underlying cause of death in only $22 \%$, defined as ICD code 343 (infantile cerebral palsy); but this increases to $26 \%$ by adding ICD code 344 (other paralytic syndromes) (compared with $34 \%$ in our study). Furthermore, $28 \%$, compared with 59 of $282(21 \%)$ in our study were attributed to the ICD "respiratory chapter", mostly pneumonias.

For England and Wales, the Office for National Statistics (through its death certification advisory group) has been reviewing ways of improving the quality of death certification, focusing initially on the certificate for deaths after 28 days of life. The need for better educational materials, to guide death certificate completion and referral to the coroner, prompted the launch of an educational video cassette pack with pocket guidelines in 1996. "Death counts" was aimed at medical students, general practitioners, and junior hospital doctors. ${ }^{28}{ }^{29}$ In 1996, the Deputy Chief Medical Statistician also wrote to all doctors via general practices and hospital consultants updating previous guidance from $1990 .^{30}{ }^{31}$ Since 1997, updated death certification instructions have been included in the death certification books. The format of this death certificate ${ }^{32}$ remains unchanged, however, and such efforts to improve death certification should continue to take effect for some years.

The important role of cerebral palsy registers in highlighting the changing prevalence of cerebral palsy is well documented. Our analysis of the certified causes of death in cerebral palsy has complemented the findings from another cerebral palsy register. It has also provided a rare cause specific insight into death certification quality from the perspective of choice of cause of death terms and their arrangement. Further research is needed into the diagnostic accuracy of death certification in cerebral palsy, and into the explanation for certifiers omitting cerebral palsy from the cause of death statement.

Cerebral palsy is the most common serious disability affecting children and might be at least a contributory cause of death more often than is currently certified. The lack of published routine data on cerebral palsy emphasises the crucial contribution of well maintained cerebral palsy registers to provide information that complements mortality data and can be extrapolated nationally.

The meticulous maintenance of the Mersey Cerebral Palsy Register by Theresa Cooke is gratefully acknowledged. Funding of the Mersey Cerebral Palsy Register (including the "flagging" of cases) has been provided from several sources: the former Mersey Regional Health Authority Research Committee; Children Nationwide; SCOPE; the former North West Regional
Health Authority Research and Development scheme; and the National Health Service Executive (North West) Regional Office Research and Development scheme. The authors are most appreciative of these sources of funding.

1 Mackenbach JP. The epidemiologic transition theory. F Epidemiol Community Health 1994;48:329-31.

2 Maudsley G, Williams EMI. Inaccuracy in death certification-where are we now? f Public Health Med 1996;18:59-66.

3 James G, Patton RE, Heslin AS. Accuracy of cause-of-death statements on death certificates. Public Health Rep 1955;70: $39-51$.

4 Heasman MA, Lipworth L. Accuracy of certification of cause of death: a report on a survey conducted in 1959 in 75 hospitals of the National Health Service to obtain information on the extent of agreement between clinical and post-mortem diagnoses. Studies on medical and population subjects no. 20. London: HMSO, General Register Office, 1966.

5 Alderson MR, Meade TW. Accuracy of diagnosis on death certificates compared with that in hospital records. $\mathrm{Br} \mathcal{F}$ Prev Soc Med 1967;21:22-9.

6 Medical Services Study Group of the Royal College of Physicians of London. Death certification and epidemiological research. BM7 1978;ii:1063-5.

7 Cameron HM, McGoogan E. A prospective study of 1152 hospital autopsies; (I) inaccuracies in death certification. $\mathcal{F}$ hospital autopsies; (I) in $1981 ; 133: 273-83$.

8 Cameron HM, McGoogan E. A prospective study of 1152 hospital autopsies: (II) analysis of inaccuracies in clinical diagnosis and their significance. I Pathol 1981;133:285300 .

9 Benavides FG, Bolumar F, Peris R. Quality of death certificates in Valencia, Spain. Am f Public Health 1989;79:13524.

10 Karwinski B, Hartveit F. Death certification: increased clinical confidence in diagnosis and lack of interest in confirmation by necropsy is not justified. 7 Clin Pathol 1989;42:13-17.

11 Nielsen GP, Bjornsson J, Jonasson JG. The accuracy of death certificates: implications for health statistics. Virchows Archiv A Pathol Anat Histopathol 1991;419:143-6.

12 Maudsley G, Williams EMI. Death certification by house officers and general practitioners-practice and performofficers and general practitioners-practice
ance. F Public Health Med 1993;15:192-201.

13 Leadbeatter S. Semantics of death certification. $7 R$ Coll Physicians Lond 1986;20:129-32.

14 Fernando R. Medical certification of cause of death in the General Hospital, Colombo. Ceylon Med f 1990;35:71-4.

15 Maudsley G, Williams EMI. Death certification — a sad state of affairs [letter]. F Public Health Med 1994;16:370-1.

16 Tokuhata G, Miller W, Digon E, Hartman T. Diabetes mellitus: an underestimated public health problem. $\mathcal{F}$ Chronic Dis 1975;28:23-35.

17 Balkau B, Jougla E, Papoz L, and the EURODIAB Subarea C Study Group. European study of the certification and coding of causes of death of six clinical case histories of diabetic patients. Int $\mathcal{F}$ Epidemiol 1993;22:116-26.

18 Ingemar B, Lindahl B, Allander E. Problems in the classification of death diagnoses affecting the reliability of cation of death diagnoses affecting the reliability of
mortality statistics for rheumatoid arthritis. $\mathcal{F}$ Chronic Dis mortality statistics

19 Evans PM, Alberman E. Certified cause of death in children and young adults with cerebral palsy. Arch Dis Child 1990; 65:325-9.

20 Pharoah POD, Cooke T, Cooke RWI, Rosenbloom L. Birthweight specific trends in cerebral palsy. Arch Dis Child 1990;65:602-6.

21 Pharoah POD, Platt MJ, Cooke T. The changing epidemiology of cerebral palsy. Arch Dis Child 1996;75:F169-73.

22 Hutton JH, Cooke T, Pharoah POD. Life expectancy in children with cerebral palsy. BMf 1994;309:431-5.

23 Pharoah POD, Cooke T, Rosenbloom L, Cooke RWI. Trends in birth prevalence of cerebral palsy. Arch Dis Child 1987;62:379-84.

24 Bax M. Terminology and classification of cerebral palsy. Dev Med Child Neurol 1964;6:295-7.

25 World Health Organisation. Manual of the international classification of diseases, injuries and causes of death, Vol. 1, 9th revision. London: HMSO, 1977.

26 Office for National Statistics. Mortality statistics: cause: review of the Registrar General on death by cause, sex, and age, in England and Wales, 1997. (Series DH2 no. 24). London: The Stationery Office, 1998.

27 Rooney C, Devis T. Mortality trends by cause of death in England and Wales 1980-94: the impact of introducing automated cause coding and related changes in 1993. Popul Trends 1996;86:29-35.

28 Office for National Statistics. Death counts (video cassette pack). London: Office for National Statistics, 1996.

29 Pain CH, Aylin P, Taub NA, Botha JL. Death certification: production and evaluation of a training video. Med Educ production and

30 Ashley J. Completion of medical certification cause of death [letter]. London: Office of Population, Censuses and Surveys, 1990

31 Coleman MP. Death certification and referral to the coroner [letter]. London: Office for National Statistics, 1996

32 OPCS to pilot revised medical certificate of cause of death. Office of Population Censuses and Surveys Newsletter 1995;3:3. 